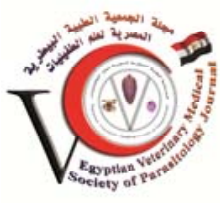

Original Article

\title{
Molecular diagnosis of Eimeria stiedae in hepatic tissue of experimentally infected rabbits in comparison with traditional methods
}

Khaled M Hassan ${ }^{1}$,
Mahmoud A El-Askalany ${ }^{2}$,
Waheed M Mousa ${ }^{3}$,
Khaled AM Shokier',
Waleed M Arafa',
Shawky M Aboelhadid ${ }^{2}$
${ }^{1}$ Animal Health Research
Institute, Beni Suef Branch
${ }^{2}$ Parasitol Department, Faculty
of Veterinary Medicine, Beni
Suef University
${ }^{3}$ Parasitol Department, Faculty
of Veterinary Medicine, Cairo
University

Khaled M Hassan ${ }^{1}$, Mahmoud A El-Askalany ${ }^{2}$ Waheed M Mousa ${ }^{3}$, Khaled AM Shokier ${ }^{1}$ Waleed M Arafa ${ }^{2}$ Shawky M Aboelhadid ${ }^{2}$ ${ }^{1}$ Animal Health Research Institute, Beni Suef Branch ${ }^{2}$ Parasitol Department, Faculty of Veterinary Medicine, Beni Suef University culty University

\begin{abstract}
:
The early detection of Eimeria stiedae stages in hepatic tissue of experimentally infected rabbits was studied. The experiment was conducted using 40 male New Zealand rabbits of six weeks age. The rabbits were divided into an infected group (A) of 30 rabbit and a control uninfected group (B) of ten rabbits. Group A was infected with $2.5 \times 10^{4}$ sporulated oocysts of E. stiedae per rabbit at zero day. Three rabbits of group $A$ and one of group B were sacrificed at $0,3,6$, 9, 12, 15,18,21,24 and 27 day post-infection. Gross findings, light microscopy, transmission electron microscopy (TEM) and molecularly with PCR were applied to detect specific findings of E. stiedae in the liver tissue pre- and post- shedding of oocysts in the feces. Grossly, liver showed irregular yellowish white nodules appeared from the $15^{\text {th }}$ days postinfection and became more prominent gradually. Hepatomegaly and ascites were obvious from the 21-24th day post-infection. Histopathologically, different schizonts and gametocytes of E. stiedae in the biliary epithelium appeared at the $15^{\text {th }}$ day post-infection. Findings of TEM were matched with the light microscopy. PCR showed positive findings starting from the $12^{\text {th }}$ day post-infection using specific E. stiedae primers and its specific amplicon of E. stiedae (976 $\mathrm{bp})$. The shedding of oocysts began from the $17^{\text {th }}$ day post- infection and reached the peak at the 23-25th day PI, then began to decline until the end of the study. In conclusion, the convention PCR detected Eimeria schizont from the $12^{\text {th }}$ day post- infection earlier to PM lesions or before shedding of the oocysts in feces.
\end{abstract}

Key words: Eimeria stiedae, rabbits, experimental infection, PCR

\section{INTRODUCTION}

Coccidiosis has a particular importance in rabbit colonies. It is a highly contagious protozoal infection. It is caused by Eimeria species which are highly host, organ and tissue specific (Levine, 1985; Georgi and Georgi, 1990). Rabbit coccidiosis always present in rabbits farms and its eradication is very hard (Vancraeynest et al., 2008). Hepatic coccidiosis ( $E$. stiedae) is one of the most pathogenic coccidian protozoans in domestic rabbits causing severe disease and a high mortality (Hauptman et al., 2001; Al-Mathal, 2008).

Eimeria stiedae is an inhabitant of the epithelial cells of the bile ducts and cause severe liver damage in rabbits (Yakhchali and Tehrani, 2007; Once et al., 2011; Abed and Yakoob, 2013). It causes proliferation of bile duct epithelial cells and the affected livers contained multifocal, well-demarcated, linear, yellow lesions due to the course of the biliary tree (Hobbs and Twigg, 1998). The use of the biotechnological advances gave a significant step to improve the prevention and control of coccidiosis in poultry farms (Morris and Gasser, 2006). Schnitzler et al. (1999), Lew et al. (2003) and Su et al. (2003) used ITS-1 as a target for PCR to identify chicken Eimeria species. Oliveira et al. (2011) developed a molecular assay to differentiate between 11 Eimeria species in rabbits. So, the present study tries to use the molecular assay to investigate $E$. stiedae course in hepatic tissue and blood of experimentally infected rabbits. Also, comparing it with traditional methods at different intervals of the life cycle in order to achieve the most accurate results for early detection of the disease and its follow up in the patent period.

\section{MATERIALS AND METHOdS}

\section{Rabbits}

Forty male healthy New Zealand rabbits, aged 6 weeks and weighing 1-1.5 kg, were used. During the experiment, the rabbits were individually housed in metal cages with a metallic grid on the bottom keeping rabbits from coming in contact with their feces. The rabbits were fed with commercial pellet food and water was supplied ad libitum. 
The absence of $E$. stiedae and other coccidian oocysts prior to the experiments was confirmed by fecal examination using floatation method daily for two successive weeks to confirm that rabbits are free from coccidian infection.

\section{E. stiedae oocysts}

Previous molecularly identified E. stiedae oocysts (Hassan et al., 2014) were allowed to sporulate in $2.5 \%$ potassium dichromate solution ( $\geq 3$ days).

\section{Experimental infection of Rabbits with $E$. stiedae oocysts}

The rabbits were divided into two groups; group $A$ of 30 infected rabbits and group $B$ of 10 control uninfected rabbits. Each rabbit of group $A$ was challenged with a dose of $2.5 \times 10^{3}$ sporulated oocysts of $E$. stiedae. Three rabbits of group $A$ and one animal of group $B$ were sacrificed at 0 , $3,6,9,12,15,18,21,24$ and 27 day post-infection.

\section{E. stiedae cycle in the infected rabbits was investigated through the following parameters:}

\subsection{Parasitologically:}

\subsubsection{Prepatent and patent period:}

The fecal samples of each infected animal were collected daily and examined microscopically for the appearance and existence of coccidian oocysts. The prepatent and patent period were stated.

\subsubsection{Oocyst shedding rate:}

Fecal samples were collected daily for parasitological examination beginning from oocyst excretion in feces until the $27^{\text {th }}$ day post challenge and number of oocysts per gram feces was counted using the McMaster method (Long and Joyner, 1976).

\subsection{PM \& Histopathological lesions:}

PM investigations of slaughtered rabbits were thoroughly carried out for the gross lesions and any abnormal gross changes in the internal organs. Tissue specimens were taken and rapidly fixed in $10 \%$ neutral buffered formalin, embedded in paraffin, sectioned (4-5 $\mu \mathrm{m})$ and mounted on glass slides. Sections were stained with hematoxylin and eosin (HE) for light microscopic examination (Culling, 1983).

\subsection{Electron microscope trans-sectioning}

Liver tissues were fixed immediately in 3\% glutaraldehyde in $0.1 \mathrm{M}$ Sodium cacodylate buffer $(\mathrm{pH} 7.3-7.4)$ for at least 4 hours at $4^{\circ} \mathrm{C}$ and were sent to Zoology Department, College of Science, Ein shams University for electron microscopic examination. The specimens were washed overnight in the same buffer at 4 ㅇ $\mathrm{C}$ and post-fixation in $2 \%$ osmium tetroxide in the same buffer for $2 \mathrm{~h}$ at $4^{\circ} \mathrm{C}$.
Specimens were rinsed twice in the same buffer for $10 \mathrm{~min}$ before dehydrated in ascending series of ethanol and finally were embedded in araldite. Semi-thin sections were cut with Leica ultracut UC7 and were stained with toluidine blue for light microscopic examination. Ultra-thin sections were stained with uranyl acetate and lead citrate and finally were examined with JEOL-JSM-1011 electron microscopy at 80-100 kV (Al-Ghamdy et al., 2005; Ball et al., 2014).

\subsection{Molecular detection of $E$. stiedae in the liver tissue and blood}

DNA was extracted from blood samples of infected rabbits slaughtered at (3,6 and 9) day post infection and from liver tissues at $(3,6,9,12,15$ and 18$)$ day post infection using extraction kit (Biobasic, Inc., Canada, Cat. No. BS427) according to Guven et al. (2013). Following the kits instructions briefly; the samples were mixed with the kit lysis buffer, $\mathrm{ACL}$ solution $(300 \mu \mathrm{L}$ sample $+300 \mu \mathrm{L}$ lysis buffer) and $20 \mu \mathrm{L}$ Protienase $\mathrm{K}$ were added, and the mixture was incubated at $56^{\circ} \mathrm{C}$ till lysis was complete (achieved after 3 hours). The DNA samples (100 $\mu$ l) were collected after loading on the mini spin column of the kit. The DNA was eluted in $50 \mu \mathrm{L}$ of elution buffer included in the same kit. DNA extracts were stored at $-20^{\circ} \mathrm{C}$ for using in PCR.

\section{DNA amplification:}

Purified DNA extracts of infected liver or blood samples were analyzed with PCR. Primers (Es1F/R) according to Yan et al. (2013) (forward primer, ACCATGGGTCGGTTCGGTC, reverse primer ATGCGCGCGCCAACAAGCTAC). PCR master mix amplification kit (Gen aid) was used. PCR reactions were performed under the following conditions: initial denaturation for $3 \mathrm{~min}$ at $94^{\circ} \mathrm{C}$ followed by 40 cycles of denaturation for $45 \mathrm{~s}$ at $94^{\circ} \mathrm{C}$, annealing for $45 \mathrm{~s}$ at $57^{\circ} \mathrm{C}$, and extension for $1 \mathrm{~min}$ at $72^{\circ} \mathrm{C}$. Final extension at $72^{\circ} \mathrm{C}$ was allowed to proceed for $10 \mathrm{~min}$. PCR products were detected in $1 \%$ agarose electrophoresis.

\section{RESULTS}

\section{Parasitologically:}

The first oocyst shedding in feces was observed on day 17 PI (prepatent period was 17 days), and oocysts were shed in considerable amounts until the end of the study. The peak period of oocysts shedding reached to the maximum in the 23,24 and $25^{\text {th }}$ days post infection then declined (Table 1). 
Table 1: The oocysts count per gram of feces in last four sacrificed rabbits ( $3 \mathrm{gr}$. A and $1 \mathrm{gr}$. B)

\begin{tabular}{|c|c|c|c|c|c|}
\hline Day & Rabbit & $\begin{array}{c}\text { R1 } \\
\text { (Rabbit. 1. infected) }\end{array}$ & $\begin{array}{c}\text { R2 } \\
\text { (Rabbit. } 2 \text { inf.) }\end{array}$ & $\begin{array}{c}\text { R3 } \\
\text { (Rabbit. } 3 \text { inf.) }\end{array}$ & $\begin{array}{c}\text { Control uninfected } \\
\text { Rabbit }\end{array}$ \\
\hline 17 & & 500 & 100 & 140 & 0 \\
\hline 18 & & 1600 & 210 & 3600 & 0 \\
\hline 19 & & 3200 & 18000 & 13200 & 0 \\
\hline 20 & & 16000 & 42000 & 80000 & 0 \\
\hline 21 & & 33000 & 87000 & 250000 & 0 \\
\hline 22 & & 102000 & 195000 & 550000 & 0 \\
\hline 23 & & 131000 & 225000 & $\underline{600000}$ & 0 \\
\hline 24 & & 184000 & $\underline{240000}$ & 480000 & 0 \\
\hline 25 & & $\underline{900000}$ & 105000 & 500000 & 0 \\
\hline 26 & & 400000 & 120000 & 480000 & 0 \\
\hline 27 & & 360000 & 27000 & 200000 & 0 \\
\hline
\end{tabular}

*Shedding of oocyst begin from the 17 day post infection and the peak period reached to the maximum in the 23,24 and $25^{\text {th }}$ days post infection then declined.
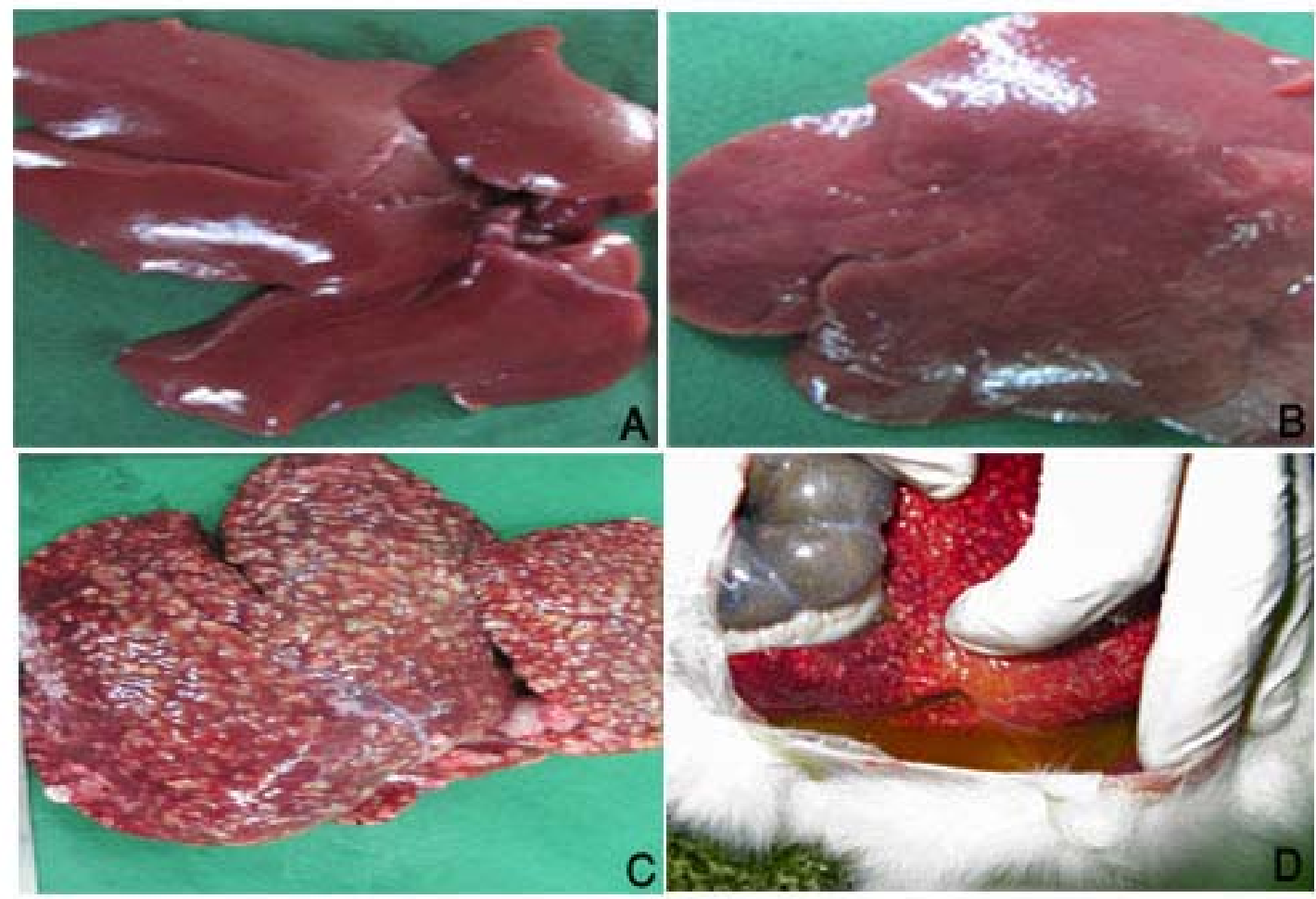

Figure 1: (A) Normal liver (B) liver at the $15^{\text {th }}$ day post infection (C) liver at the $27^{\text {th }}$ day post infection (D) ascites at the $24^{\text {th }}$ day post infection

\section{Gross lesions:}

The PM findings showed the liver had irregular yellowish white nodules scattered on the surface beginning from $15^{\text {th }}$ day post-infection and became more prominent gradually, these nodules contained white caseous material. The parenchyma was severely congested and edematous. Hepatomegaly and ascites were obvious from the $21-24^{\text {th }}$ days post infection. Gall bladder was distended with pale greenish fluid which turned yellowish at the end of study (Fig. 1).

\section{Histopathological pictures:}

The main histopathological appearance was the hyperplasia of the bile duct epithelial lining which begin from the $9^{\text {th }}$ day post infection accompanied by degenerative changes and necrosis in the hepatic cells surrounded by inflammatory cells, then the hyperplasia of bile duct epithelium became more extensive forming long papillary projections and desquamation of some epithelial folds into the ductal lumen with the presence of mature schizonts and gametocytes in the epithelium of the bile 

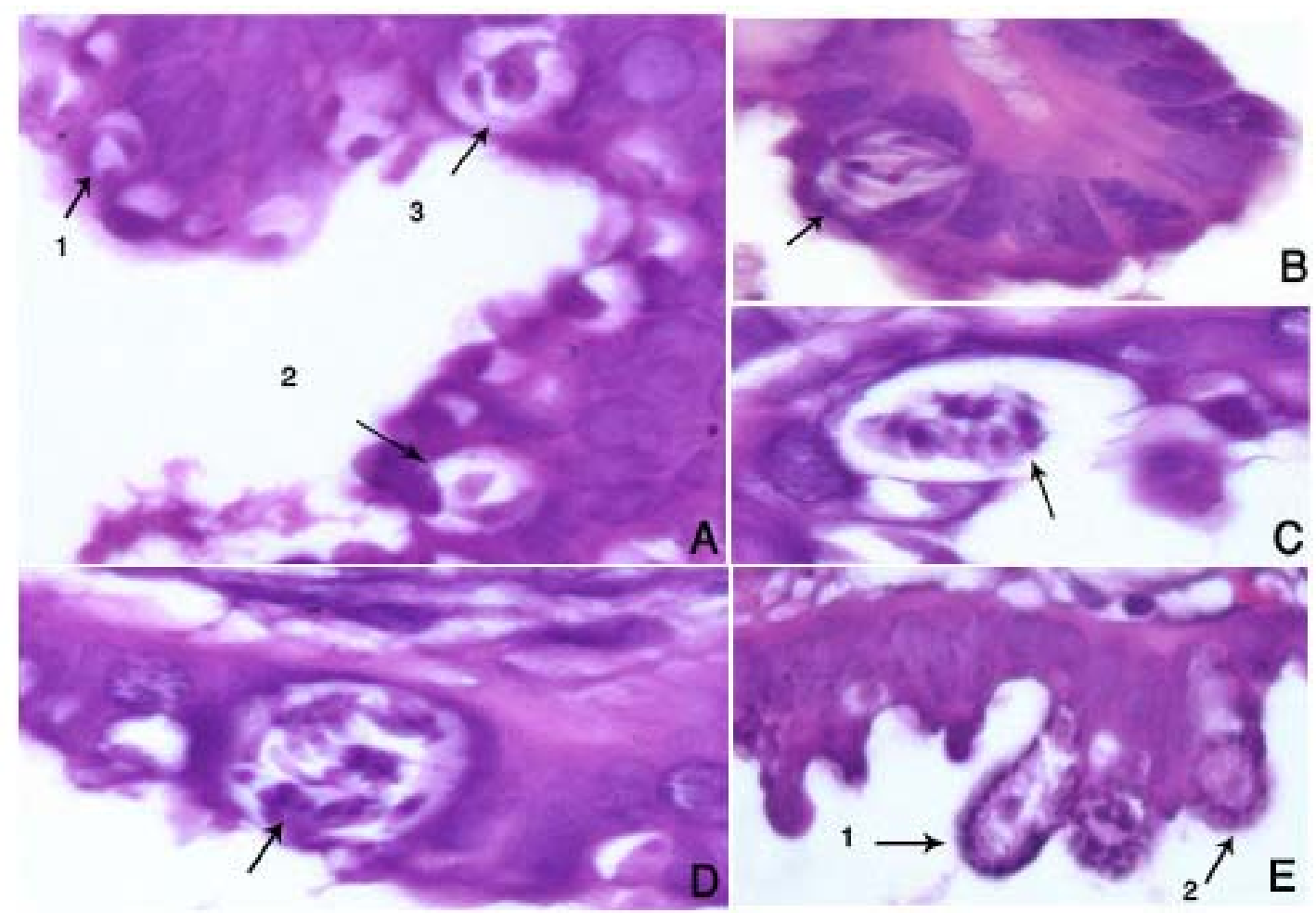

Figure 2: The different schizonts and gametocytes at the $15^{\text {th }}$ day post infection: (A) 1-one merozoite 2-two merozoites 3- four merozoites (B) 8 merozoites (C) 16 merozoites (D) 32 merozoites (E) 1- macrogametocytes 2- microgametocytes.

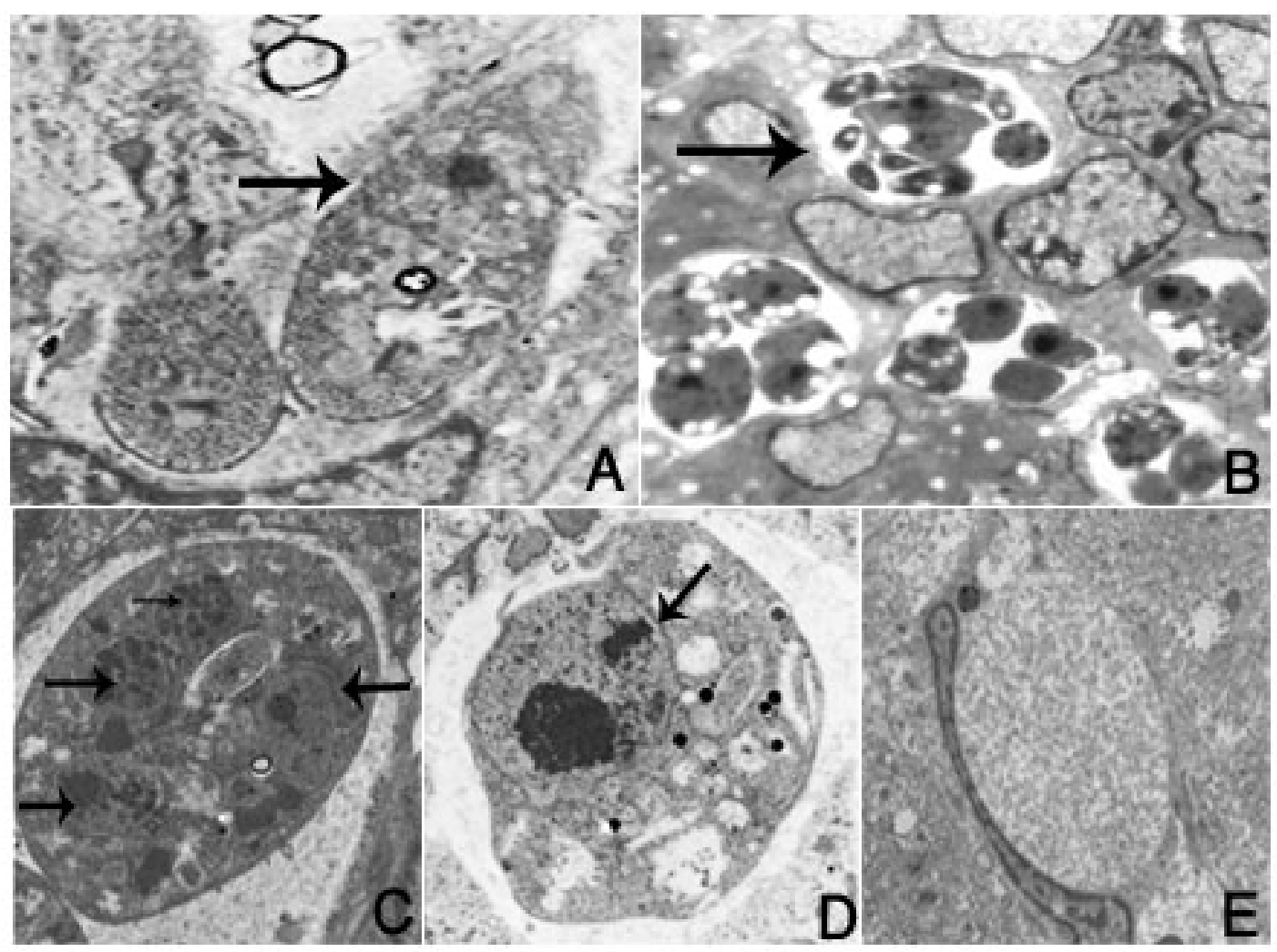

Figure 3: The developmental stages at the $15^{\text {th }}$ day post infection and the oocysts in the bile duct epithelium at the $18^{\text {th }}$ day post-infection. A- merozoite B-different schizonts C-microgamete (multinucleated) D-macrogamete (contain one nucleus) E-oocyst 


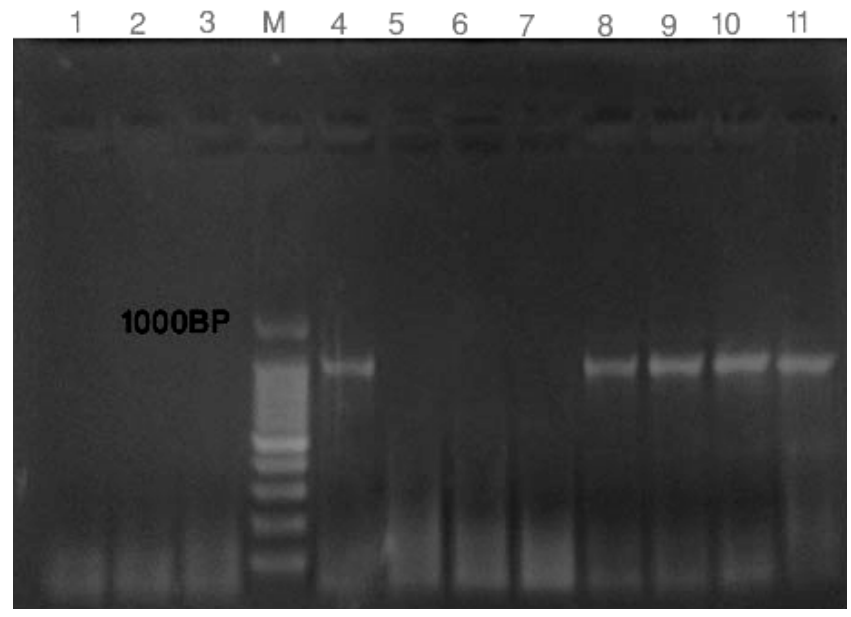

Figure 4: The blood samples were taken on days $3^{\text {rd }}, 6^{\text {th }}$ and $9^{\text {th }}$; are negative (lanes $1,2 \& 3$ ). The processed liver samples were taken on days $3^{\text {rd }}, 6^{\text {th }}$ and $9^{\text {th }}$; are negative (lanes $5,6, \& 7$ ) and the samples of liver tissues that were processed for PCR from the $12^{\text {th }} 15^{\text {th }}$ and $18^{\text {th }}$ post infection were positive at the amplicon size 976 bp of $E$. stiedae with Agarose gel electrophoresis. In addition lane 4 control positive and lane 11 positive fecal sample.

ducts at the $15^{\text {th }}$ day post-infection. Moreover, the hyperplastic bile ducts surrounded by large amounts of fibrous connective tissue infiltrated with mononuclear cells and the hepatic parenchyma showed dilation and congestion of central veins and sinusoids with the rupture of lining endothelial layer (Fig. 2).

\section{Trans-sectioning by EM:}

The results of electron microscope were parallel with that of histopathology, which revealed different shizonts and gametocytes in the epithelium of the bile ducts at the $15^{\text {th }}$ day post infection and oocysts in bile duct epithelium at the $18^{\text {th }}$ post-infection (Fig. 3 ).

\section{PCR findings:}

The collected blood samples from the zero day of infection then at the $3^{\text {rd }}, 6^{\text {th }}$ and $9^{\text {th }}$ days post infection were negative for PCR. In addition, the PCR results showed that no evidence of sporozoites migration in liver tissues in the $1^{\text {st }}$ week of infection till the $12^{\text {th }}$ day post infection. Mean while, the samples of liver tissues that were processed for PCR from the $12^{\text {th }}$ post infection and the next periods of investigation $\left(15^{\text {th }}, 18^{\text {th }}\right.$ tillthe end of the experiment) were found positive at the amplicon size 976bp of E. stiedae with Agarose gel electrophoresis (Fig. 4).

\section{Discussion}

In the present study, the macroscopic examination of liver of experimentally infected rabbits revealed the irregular yellowish white nodules scattered on the surface at the $15^{\text {th }}$ day post-infection and became more prominent gradually, hepatomegaly and ascites were obvious from the $21-24^{\text {th }}$ days post-infection. The selections are characteristic for E. stiedae infection (Al-Naimi et al., 2012; Abed and Yakoob, 2013). Hepatomegaly was due to marked proliferation and distention of bile ducts forming nodules raised above the surface causing increase in the secretion of mucous appeared as a creamy white fluid in cut surface (Al-Mathal, 2008; Al-Naimi et al., 2012). The occurrence of those coccidian nodules is due to the toxic effect of the protozoon settled in the liver (Barriga and Arnoni, 1979).

Microscopically, the developmental stages of $E$. stiedae and most significant lesions were noticed in the biliary epithelium at the $15^{\text {th }}$ day post infection. The histopathological observations are similar to those observed by (El-Akabawy et al., 2004; Abu-Akkada et al, 2010; Al-Naimi et al., 2012). The proliferation of the bile duct epithelium might be due to the multiplication of $E$. stiedae within the epithelium lead to sinusoidal dilatation, associated with fibrosis in and around the cords lead to the obstructed hepatic blood flow especially in the portal veins by immensely proliferating and dilating bile ducts, the stagnation of the blood flow would also result in hepatocellular degeneration and atrophy of the cords (Singla et al., 2000; Al-Naimi et al., 2012).

Examination by electron microscope revealed different schizonts in the epithelium of bile ducts at the $15^{\text {th }}$ day post infection, this nearly in agreement with Černá and Sénaud (1971) and Hung et al. (1984) whom observed different schizogony stages at the $13^{\text {th }}$ day post infection. Mean while El-Masry (1983) and Li and Wang (1989) mentioned that large number of fully mature schizonts containing various numbers of merozoites could be detected in most bile ducts at the $10^{\text {th }}$ day post infection. Regarding the gametogony stages, were noticed in the epithelial of bile ducts at the $15^{\text {th }}$ and $16^{\text {th }}$ day post infection, this finding also reported by Kheysin (1972) and El-Masry (1983) whom recorded the gametogony stages at the (15 and $16^{\text {th }}$ day post infection) respectively. Another studies by Mining (1936) and Soulsby (1968) found the gametogony stages in the $11-13^{\text {th }}$ days post infection. The variance in schizonts and gamogony stages 
may be referred to the rabbit breed, and the parasites strain in the view of authors.

The prepatent period was observed at the $17^{\text {th }}$ day post infection, similar results were detected by (Abu-Akkada et al, 2010; Abu-El-Ezz et al, 2012), slight difference recorded with the results of Soulsby (1968) and Shameem and Devada (2005), whom found the prepatent period on the $18^{\text {th }}$ day post infection. Comparable results were observed by Levine (1973) and Cam et al. (2008), in which they recorded the first oocyst shedding on the $6-9^{\text {th }}$ days post-infection. While Jibike et al. (1995) recorded prepatent period at the $11^{\text {th }}$ days post infection. Moreover, Gomez-Bautista et al. (1987) and Wang and Tsai (1993) found the prepatent period at the $\left(14-15^{\text {th }}\right)$ day post infection respectively. In contrary, Smetena (1933) and Barriga and Arnoni (1981) reported that the first oocystic shedding appeared at the $3^{\text {rd }}-4^{\text {th }}$ week postinfection. The peak of oocyst shedding was recorded in the 23,24 and $25^{\text {th }}$ days post infection then began to decline until the end of the study. These results were nearly parallel with Kutkat et al. (1998) and AbdelMegeed and Abu-El Ezz (2005), while (Lammler and Hein, 1981; Abu-Akkada et al., 2010) observed that the highest oocysts concentration was seen between the $17^{\text {th }}-21^{\text {st }}$ days post infection. On the other hand, Balbaa et al. (2012) recorded the maximum oocysts shedding at the $26^{\text {th }}$ day post infection. This difference in the oocysts count might be due to $E$. stiedae oocysts infection dose and age susceptibility of rabbits (Abu-El-Ezz et al., 2012). Also, we think that the animal breed may be of a role in this.

Purified DNA extracts of infected liver samples were analyzed with PCR. Primers (Es1 F/R) according to (Yan et al., 2013) who developed and used a specific and sensitive multiplex PCR diagnostic assay based on polymorphic sites of ITS1 and ITS2 to identify the three highly pathogenic species from rabbits, E. stiedae, E. intestinalis, and $E$. flavescens.

Consequently, this study investigated $E$. stiedae in liver tissue of experimentally infected rabbits with PCR. We succeeded to detect it from the $12^{\text {th }}$ day post infection. In addition PCR results confirmed those obtained from parasitological, histopathological and electron microscopic examinations. Moreover, this early detection of infection helps in early treatment and before deleterious effects of $E$. stiedae are advanced.

\section{REFERENCES}

Abdel-Megeed, K.N. and Abu El-Ezz, N.M.T. (2005): Control of Hepatic coccidiosis in rabbits using Calendula micranthaofficinalis and Peganumharmala extracts. Egypt. J. Vet. Sci., 39: 34-45.

Abed, H.H. and Yakoob, A.Y. (2013): Study the protective and therapeutic effect of crude garlic on mortality, oocyst output and hepatic lesions in experimentally infection with Eimeria stiedae in domestic rabbits. Bas. J. Vet. Res. 12(2):314-331.

Abu-Akkada, S.S., Oda, S.S. and Ashmavy K.I. (2010): Garlic and hepatic coccidiosis: prophylaxis or treatment? Tropical Animal Health and Production 42: 1337-1343.

Abu-El-Ezz, N.M.T., Abdel-Megeed, K.N., Mahdy, O.A. and Hassan, S.E. (2012): ELISA Assessment in the Diagnosis of Hepatic Coccidiosis in Experimentally Infected Rabbits. Glob. Vet. 9 (5): 517-523.

Al-Ghamdy, A.O., Shazly, M., Al-Rasheid, K.A., Mubarak, M. and Bashtar, A. (2005): Light and electron microscopy of Eimeria magna Perard, 1925 infecting the house rabbit, Oryctolagus cuniculus from Saudi Arabia. II. Gamogony and oocyst wall formation. Saudi J. Biol. Sci., 12:114-125.

Al-Mathal, E.M. (2008): Hepatic Coccidiosis of the Domestic Rabbit (Oryctolagus cuniculus domesticus L.) in Saudi Arabia. World Journal of Zoology 3 (1):30-35.

Al-Naimi, R.A.S., Khalaf, O.H., Tano, S.Y. and Al-Taee, E.H. (2012): Pathological study of hepatic coccidiosis in naturally infected rabbits. Al-Qadisiya J. Vet. Med. Sci., 11: 63-69.

Balbaa, M., El-Hady, N.A., Taha, N. and El-Ashry, E.H. (2012): Some heterocyclic thione derivatives exhibit anticoccidial activity by inhibiting glycosidases. Acta Biochimica Polonica. 59: 4:575-580.

Ball, S.J., Pittilo, M.R. and Snow, K.R. (2014): Observations on oocyst development of Eimeria stiedae in rabbits. Exp. Parasitol. 147:16-22.

Barriga, 0.0. and Arnoni, J.U. (1979): E. stiedae weight, oocyst output and hepatic function of rabbits with graded infection. Experimental Parasitology, 48,407-414.

Barriga, 0.O. and Arnoni, J.V. (1981): Pathophysiology of hepatic coccidiosis in rabbits. Vet. Parasito. 8(3):201-210.

Cam, Y., Atasever, A., Eraslan, G., Kibar, M., Atalay, O., Beyazi, L., Inci, A. and Liman, B.B. (2008): Eimeria stiedai: Experimental infection in rabbits and the effect of treatment with toltrazuril and ivermectin. Exp. Parasitol., 119: 164-172.

Černá, Ž.A and Sénaud, J. (1971): Some peculiarities of the fine structure of merozoites of Eimeria stiedai. Folia Parasitol. 18: 177-178.

Culling, C.F. (1983): Handbook of histological and histochemical techniques. $3^{\text {rd }}$ ed., Butterwoth, London, Boston.

El-Akabaway, L.M., Zayan, K.A., Tantaway, A.A. and Omar, R.E.M. (2004): Anticoccidial efficacy of propolis and Toltrazuril against Eimeria stiedae in new Zealand White Rabbit s. ag. Vet. J. 32(1):129-145. 
El Masry, N.M.M. (1983): Problems of coccidiosis in rabbits [Master Thesis]. [Zagazig (Egypt)]: Zagazig University.

Georgi J.R. and Georgi M.E. (1990): Protozoans. In: Parasitology for Veterinarians, 5th edition, W.B. Saunders, Philadelphia, 34-87.

Gomez-Bautista, M., Rojo-vasquez, F.A. and Alunda, J.M. (1987): The effect of the host's age on the pathology of Eimeria stiedai infection in rabbits. Vet. Parasito. 24 (1-2): 47-57.

Guven, E., Beckstead, R.B., Kar, S., Vatansever, Z. and Karaer, Z. (2013): Molecular identification of Eimeriaspecies of broiler chickens in Turkey. Ankara Üniv. Vet. Fak. Derg. 60: 245-250.

Hauptman, K., Tichy, F. and Knotek, Z. (2001): Clinical diagnostics of hepathopathies in small mammals: Evaluation of importance of individual methods. Acta Vet. Brno. 70(3):297-311.

Hobbs, R.P. and Twigg, L.E. (1998): Coccidia (Eimeria spp.) of wild rabbits in Southwestern Australia. Aust. Vet. J. 76: $209-210$.

Hung, L.X., Chen, F.Q. and Lin, Y.G. (1984): Studies on the coccidia of rabbits, with a note on the endogenous stages and histopathology of Eimeria stiedae. Wuyi Sci. J., 4: 55 64.

Jibike, G. I., Onye, P.A., Egwu, G. O. and Rabo, J. (1995):

Treatment of experimental hepatic coccidiosis in rabbits with alpha difluoro-methylornithine (DFMO).Bulletin Anim. Health and Prod. Africa. 43: 4, 301-303.

Kheysin, Y.M. (1972): Life cycle of coccidia of domestic animals. Williams Heinemann medical books, Limited in Russian.

Kutkat, M.A., Zayed, A.A. and Abu-El-Ezz, N.M.T. (1998): A trial for immunization of rabbit against hepatic coccidiosis. Zagazig Vet. J., 26: 70-77

Lammler, G. and Hein, B. (1981): Efficacy of salinomycin in preventing hepatic coccidiosis in rabbits. Berliner and Munchener Tierarztliche-

Wochens-chrift 93 (22): 449-554.

Levine, N.D. (1973): Protozoan parasites of domestic animals and man-second edition. Burgers Publ. Comp., Minneapolis.

Levine, N.D. (1985): Apicomplexa- The Coccidia Proper. In: Veterinary Protozoology, lowa State University Press, Ames, lowa, 130-138, 178, 221-222.

Lew AE, Anderson GR, Minchin CM, Jeston PJ, Jorgensen WK. (2003): Inter and intra-strain variation and PCR detection of the internal transcribed spacer 1 (ITS-1) sequences of Australian isolates of Eimeria species from chickens. Vet Parasitol 2003;112:33-50.

Long, P.L. and Joyner, L.P. (1976): A guide to laboratory techniques used in the study and diagnosis of avian coccidiosis. Folia Vet. Lat. 6: 201-217.
Minning, W. (1936): ZurEntstehung der coccidian knoten in der lebervonkaninchen. Z. parasitenik. 9: 61-72.

Morris, G.M., Gasser, R.B., (2006): Biotechnological advances in the diagnosis of avian coccidiosis and the analysis of genetic variation in Eimeria. Biotechnol. Adv. 24, 590-603.

Once T., Gulegen, E., Senlik, B., Bakirci, S. (2011): Intestinal Coccidiosis in Angora rabbits (Oryctolagus cuniculus) caused by Eimeria intestinals, Eimeria perforans and Eimeria coecicolsa. YYU Veteriner Fakutesi Dergisi 22 (1):27-29.

Oliveira CU, Fraga JS, Licois D, Pakand M, Gruber A (2011): Development of molecular assays for the identification of the 11 Eimeria species of the domestic rabbit (Oryctolagus cuniculus). Vet. Parasitol 176:275-280.

Schnitzler BE, Thebo PL, Mattsson JG, Tomley FM, Shirley MW. (1998): Development of a diagnostic PCR assay for the detection and discrimination of four pathogenic Eimeria species of the chicken. Avian Pathol; 27:490-7.

Schnitzler BE, Thebo PL, Tomley FM, Uggla A, Shirley MW. (1999): PCR identification of chicken Eimeria species: a simplified read-out. Avian Pathol; 28:89-93.

Shameem, H. and Devada, K. (2005): Prevalence of rabbit coccidiosis in Thrissur. J. Vet. Parasitol. 19(1):69-70.

Singla, L.D., Juyal, P.D. and Sandhu, B.S. (2000): Pathology and therapy in naturally Eimeria stiedae infected rabbits. J. Protozool. Res., 10:185-191.

Smetena, H. (1933): Coccidiosis of the liver in rabbits. Experimental study on the exocystation of oocysts of $E$. stiedae. Archiv. Pathol., 15:175-192.

Solusby, E.J. (1968): Helminths, Arthropods and protozoa of domesticated animals. Bailliere tindall and Cassel, $6^{\text {th }} \mathrm{Ed}$. London, 615-682.

Su, Y.C., Fei, A.C., Tsai, F.M., (2003): Differential diagnosis of five avian Eimeria species by polymerase chain reaction using primers derived from the internal transcribed spacer 1 (ITS1) Sequence. Vet. Parasitol. 117, 221-227.

Vancraeynest, D.D., Gussem, M., Marien, M., Maertens, L. (2008): The anticoccidial efficacy of robenidine hydrochloride in Eimeria challenge rabbits. Pathology and hygiene, $9^{\text {th }}$ World Rabbit Congress, Verona, Italy, 11031106.

Wang, J.S. and Tsai, S.F. (1993): Endogenous stages of Eimeria stiedai in New Zealand White rabbits. J. of the Chinese Society of Vet. Sc.; 1993. 19: 1, 66-72.

Yakhchali, M. and Tehrani, A.A. (2007): Eimeriosis and pathological findings in New Zealand white rabbits. Pak. J. Biol. Sci. 7:1488-1491.

Yan, W., Wang, W., Wang, T., Suo, X., Qian, W., Wang, S. and Fan, D. (2012): Simultaneous identification of three highly pathogenic Eimeria species in rabbits using a multiplex PCR diagnostic assay based on ITS1-5.8S rRNAITS2 fragments. Vet. Parasitol. 193(1-3):284- 288. 